\title{
FUSION NUCLEAR POWER AS PERSPECTIVE FOR ACHIEVING THE DECARBONATION OF ENERGY SECTOR
}

\author{
Nikola Markoski ${ }^{1}$, Anton Čauševski ${ }^{2}$ \\ ${ }^{I}$ MSc. Postgraduate on Technical University of Munich, Department of Plasma Physics \\ ${ }^{2}$ Faculty of Electrical Engineering and Information Technologies, \\ "Ss. Cyril and Methodius" University in Skopje, \\ P.O. box 574, 1001 Skopje, Republic of North Macedonia \\ nimarkoski@gmail.com // caus@feit.ukim.edu.mk
}

\begin{abstract}
A b s t r a c t: In order to achieve the goals of a non-carbonized energy system, there are also major challenges in how to replace coal-fired power plants as base load production facilities. One option is to replace with gas power plants that are more efficient than coal-fired TPPs with lower greenhouse gas emissions as well as fUssion nuclear power plants. In this regard, fusion nuclear power plants (NPP) are a perspective for the development of new technology in nuclear production facilities. Although fusion development has been expanding for the last 60 years, it is to be expected that the next 20 years will achieve the goal of commercially using this technology for peaceful energy purposes. The paper presents an overview of the development of fusion technology, as well as the challenges and obstacles that need to be overcome in order to achieve a commercial nuclear reactor. A magnetic confinement device - Tokamak, is represented as the most advanced device for sustainable plasma burning. Properties and expectations of the latest international Tokamak (ITER) are presented.
\end{abstract}

Key words: fusion; power plant; energy

\section{ФУЗИОНА ЕНЕРГИЈА КАКО ПЕРСПЕКТИВА ЗА ПОСТИГНУВАЫЕ ДЕКАРБОНИЗИРАН ЕНЕРГЕТСКИ СЕКТОР}

\begin{abstract}
А п с т р а к т: Во насока на постигнување на целите за декарбонизиран енергетски систем се поставуваат големи предизвици како да се заменат термоцентралите (ТЕЦ) на јаглен како базни производни капацитети. Една опција е замена со гасни постројки кои се поефикасни од ТЕЦ на јаглен и имаат пониска емисија на стакленички гасови, како и со фузиони нуклеарни централи. Во таа насока, фузионите нуклеарни централи претставуваат перспектива за развој на новата технологија на нуклеарни производни капацитети. Бидејќи развојот на фузијата има експанзија во последните 60 години, за очекување е дека во следните 20 години ќе се постигне целта за комерцијално користење на оваа технологија во мирнодопски цели во енергетиката. Трудот претставува преглед на развојот на фузионата технологија, како и на предизвиците и препреките кои треба да се совладаат во насока на постигнување комерцијален нуклеарен реактор. Претставен е Токамак како најнапреден уред за постигнување затворено магнетно поле во вид на торус, за одржливо согорување на плазмата. Претставени се својствата и очекувањата од најновиот меѓународен Токамак (ITER)
\end{abstract}

Клучни зборови: фузија; електрична централа; енергија

\section{INTRODUCTION}

The energy sector is facing with drastic changes in the last few decades, mainly with deregulation as well as opening the electricity market and with implementation the technologies from renewable in energy generation. In order to achieve sustainable energy sector, three main directions of energy development are targeted, implementation of energy efficiency measures, reduction of greenhouse gas emissions and maximum utilization of renewable in energy production. With adoption and ratification the Paris Agreement and the targets of the European Energy Community, it is necessary to 
achieve decarbonization of the energy sector, which means gradual closure of coal-fired power plants and the maximum use of renewable. The main challenges is replacing the base load coal fired TPPs, where the gas fired TPPs (CC and CHP) are the short term option. The fission NPP has stagnation in new building facilities mainly because high investments and new improved safety requirements. On the other side, the fusion reaction is still option for new nuclear reactor technology. The last few years after agreement in 2006, the project of ITER fusion reactor is being built in southern France. In addition to funding, the project also brings together the scientific and $R \& D$ potentials of many countries in the world (total 35) that develop fusion technology, such as EU countries, the United States, China, Russia and others. In anticipation of the successful demonstration of the technical feasibility of nuclear fusion power plants based on the Tokamak approach in ITER, many nations around the world are now proposing Demonstration Nuclear Fusion Power Plants (DEMO) designs. DEMO will be based on design, engineering and operational experience of ITER, and is expected to be the First-Of-A-Kind (FOAK) commercially viable fusion power demonstrator in the world (even though it may never produce power to the electricity grid).

\section{PROBLEM OF ENERGY SUPPLY}

The world's total population is predicted to reach about 10 billion by the year 2050 . The population of the developing countries, who constitutes the largest part of the Earth population, is improving its living standard and increasing enormously the energy demand.

Figure 1a gives the figures of energy consumption per capita in a year for some developed countries as well as for developing ones (Macedonia needs around $1500 \mathrm{~kg}$ oil per capita in a year.) Figure $1 \mathrm{~b}$ shows the global energy mix for electricity production in 2019.

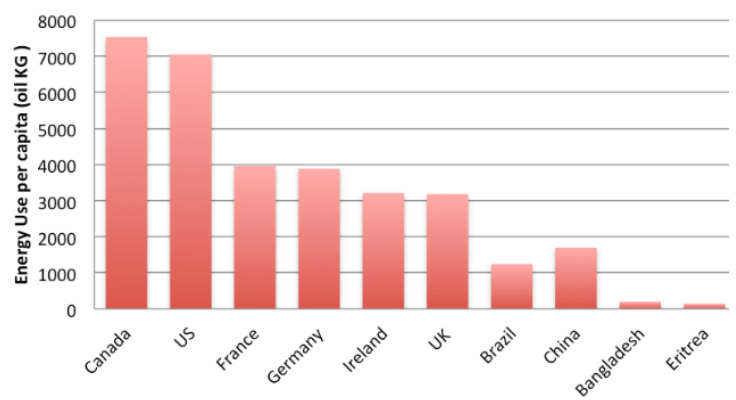

Fig. 1a. Energy use per capita (Source: World Bank)

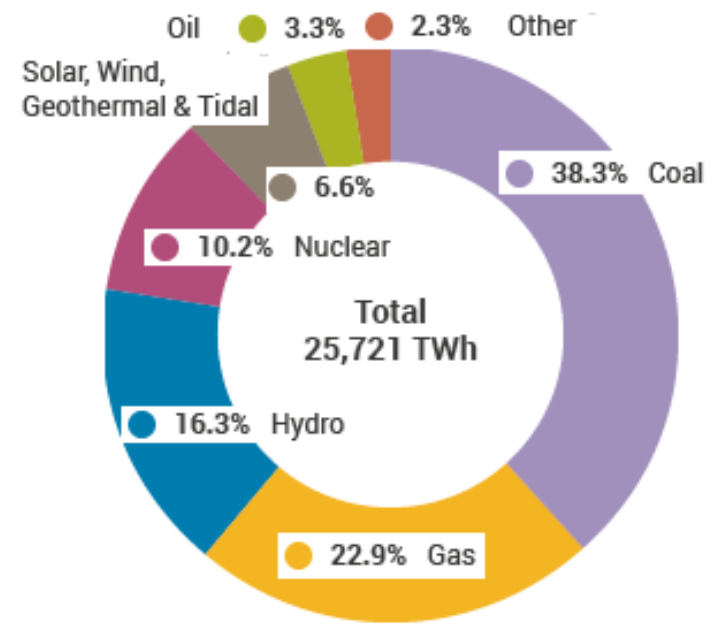

Fig. 1b. Global electricity mix in 2019 (Source: IEA)

Consequently the global electricity demand could increase by a factor of 6 until 2100 . World total energy production is increasing (Figure 2a) [1]. One of the biggest problems of electricity production is that it is still in a large part generated by coal and mineral oil (Figure 2b) [2].

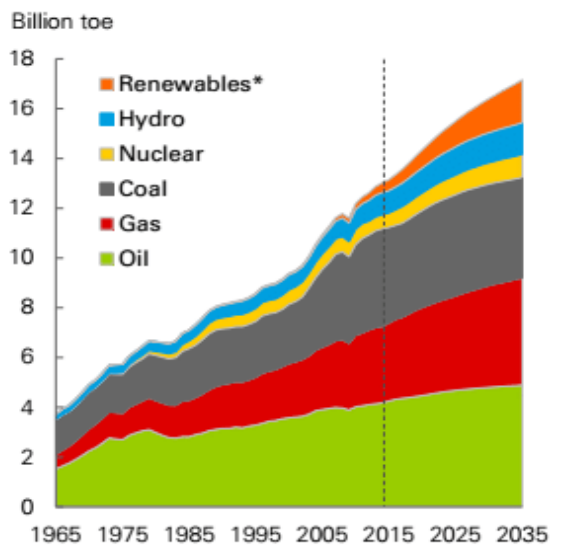

Fig. 2a. World total primary energy production

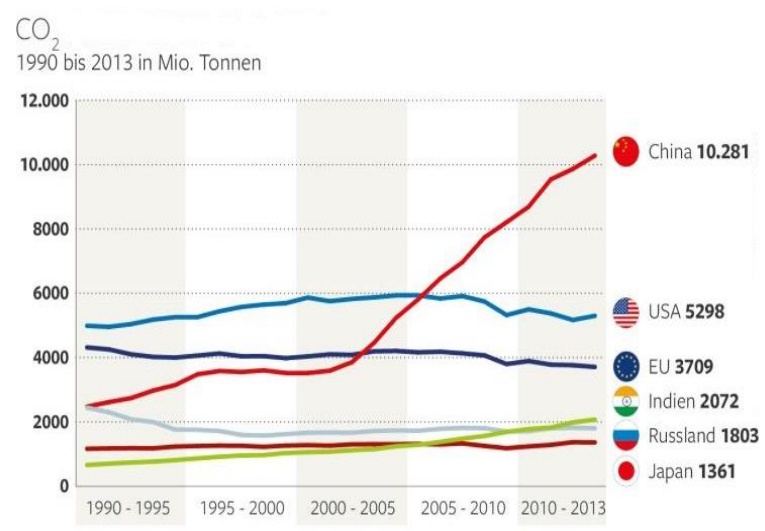

Fig. 2b. $\mathrm{CO}_{2}$ emission of some countries 
Renewable energies appear so far, not enough to cover this increase plus to substitute fossil fuels (carbon, oil, gas). Nuclear fission could play a larger role in order to reduce $\mathrm{CO}_{2}$ emission and could cover the decreasing fossil resources. However because of the danger and the 2 major accidents (Chernobyl, Fukushima), radwaste problems and the public un-acceptance, it is presently developing practically only in the eastern countries. Energy saving, birth control and welfare aiming at a more uniform well-being would be important to mitigate the demand, but it is only hypothetical in the near future. It is therefore of great importance for mankind in addition to the renewable energies to find a way to have safely and reliably extract the enormous quantity of energy that can be produced by nuclear fusion. This has the potential to release mankind from long term energy needs.

\section{NUCLEAR FUSION}

When two light nuclei fuse, the resulting heavier atomic nucleus is more tightly bound. Energy in this case is released in the form of:

- kinetic energy of the newly formed nucleus,

- kinetic energy of the nuclear fusion reaction products (neutrons).

The energy released from nuclear reactions according Einstein's formula is:

$$
\Delta E=\Delta m \cdot c^{2} .
$$

The graph on Figure 3 [4] shows that the binding energy of fusion in comparison to fission is much greater, hence the release of the energy per equivalent mass is also higher in the case of fusion.

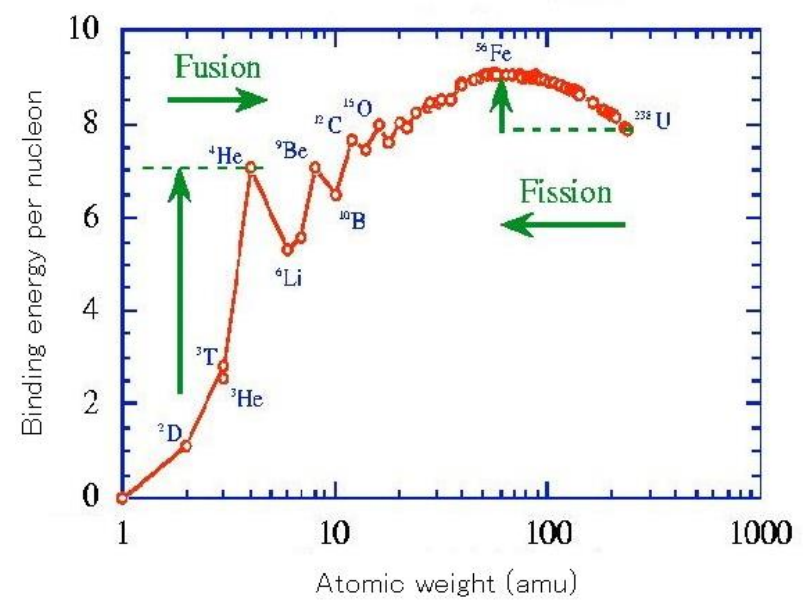

Fig. 3. Binding energy per nucleon
There exit several fusion reactions, but the most important one for 'mankind' energy generation is the deuterium-tritium (D-T) reaction.

$$
{ }_{1}^{3} \mathrm{~T}+{ }_{1}^{2} \mathrm{D} \rightarrow{ }_{2}^{4} \mathrm{He}+{ }_{0}^{1} \mathrm{n}+17.6 \mathrm{MeV} .
$$

The total energy coming from the mass defect $(17.6 \mathrm{MeV})$, released as kinetic energy of the fusion products, and is distributed according to their mass ratio $(\mathrm{He}-3.5 \mathrm{M} \mathrm{eV}, \mathrm{n}-14.1 \mathrm{M} \mathrm{eV})$. The $\mathrm{D}-\mathrm{T}$ reaction has the highest power density and highest crosssection (probability of occurrence of the reaction) at relatively 'low' temperatures. (Figure 4) [3].

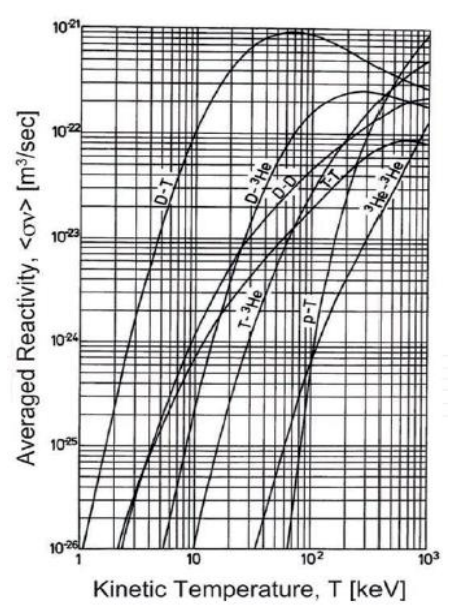

Fig. 4. Cross-section/Temperature of D-T reaction

The science, engineering and technology challenges ahead on the route to commercial fusion are vast and wide-ranging. Principally, for magnetic confinement D-T reactor concepts, the primary technical issues that must be overcome are [7], [9]:

- Stable operation of fusion plasmas.

- Design and development of a heat exhaust system (known as the diverter).

- Development of neutron-resistant fusion materials.

- Development of tritium breeding technology.

- Development of reliable magnet systems.

For the success of any fusion device, the operation and control of a high-performance plasma is crucial.

\section{OUTLINE OF A THERMONUCLEAR FUSION REACTOR}

The concept of the thermonuclear fusion reactor is presented on Figure 5 [3]. 


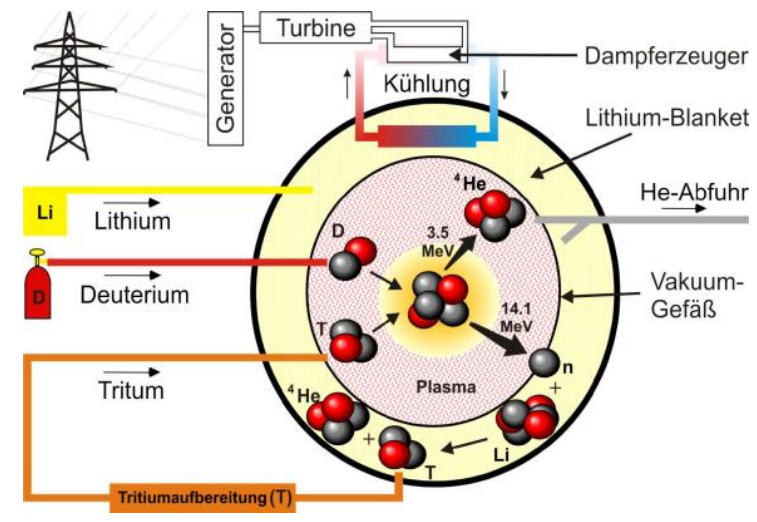

Fig. 5. Thermonuclear fusion reactor

It is consists of the following components:

- A plasma where the fusion reaction (D-T) occurs and produces the energy, releasing $\alpha$ particles and fast neutrons.

- A first wall that has to withstand and exhaust the radiative and convective heat flux and the neutron load from the fusion reactions.

- An exhaust system for the He ashes and other particles which include impurities from the walls.

- A shielding and breeder blanket that shields the outer component from heat, neutron and $\gamma$ radiation and uses the fast neutrons to generate ${ }_{1}^{3} T$, exploiting the reactions:

$$
\begin{gathered}
{ }_{0}^{1} \mathrm{n}+{ }_{3}^{6} \mathrm{Li} \rightarrow{ }_{1}^{3} \mathrm{~T}+{ }_{2}^{4} \mathrm{He}+4.78 \mathrm{MeV} \\
{ }_{0}^{1} \mathrm{n}+{ }_{3}^{7} \mathrm{Li} \rightarrow{ }_{1}^{3} \mathrm{~T}+{ }_{2}^{4} \mathrm{He}+{ }_{0}^{1} \mathrm{n}-2.5 \mathrm{MeV}
\end{gathered}
$$

- A vacuum vessel (VV) which is the first safety barrier, and is a pressure retaining part. Ultrahigh vacuum (UHV) conditions (typically $10^{-9} \mathrm{mbar}$ ) are generated inside the $\mathrm{VV}$, which is also used as a further neutron and $\gamma$ shielding.

- A UHV system consisting of several special vacuum pumps (rough, turbo molecular and cryopumps).

- The ${ }_{1}^{3} \mathrm{~T}$ and ${ }_{3}^{6} \mathrm{Li}$ supply system.

- ${ }_{1}^{3} \mathrm{~T}$ plant for the recover and reprocessing of the $\mathrm{T}$.

- For magnetic confinement the limiter a component where the plasma is started (it can be part of the first wall).

- For magnetic confinement additional components are the Superconducting Magnets.

- The heating system: for the magnetic confinement this is the external heating system (Neutral Injector System, Radiofrequency Heating System), for the inertial confinement this is the laser or ion beam accelerator system.

- The remote handling system.

- A cryostat a container to maintain the cryogenic temperature (not shown).

- The water cooling system (for the advanced reactors the He cooling system).

- For the water cooled reactors the vapor generators. The He cooling loop for a gas cooled reactor.

- The turbine and the generator for electrical power generation.

- The cooling towers.

\section{Thermonuclear power production: $D$-T case}

The output power is maximized when $n_{d}=n_{t}$. In this case the thermonuclear power produced in a $\mathrm{D}-\mathrm{T}$ plasma with a $50-50 \% \mathrm{D} / \mathrm{T}$ mixture per unit volume is:

$$
P_{D T}=\frac{1}{4} \cdot n_{D T}^{2}<\sigma v>E,
$$

where $n$ is the particle density of $\mathrm{D} / \mathrm{T},\langle\sigma v\rangle$ is the D-T reaction rate and $E$ is the energy released per reaction. In fusion devices there is also a continuous loss of energy from the plasma. The power loss is calculated by:

$$
P_{\text {loss }}=\frac{E}{\tau_{E}}=\frac{3 / 2\left(n_{e}+n_{D T}\right) \cdot K T}{\tau_{E}}
$$

Here $E$ is the total plasma energy and $\tau_{E}$ is the energy confinement time (characteristic cooling down time).

After the fusion reactions, the neutrons leave the plasma without interactions and their energy is not transferred to the plasma. The $\alpha$ particles remain confined with the plasma and can transfer their energy to the other particles by collisions or by particle-wave interactions, therefore heating the plasma. The total $\alpha$ particle heating per unit volume is:

$$
P_{\alpha}=\frac{1}{4} \cdot n_{D T}^{2}<\sigma v>E_{\alpha} V .
$$

The power balance is then:

$$
P_{\text {heating }}+P_{\alpha}=P_{\text {loss }}
$$

or

$$
P_{H}+\frac{1}{4} n_{D T}^{2}<\sigma v>E_{\alpha} V=\frac{3 / 2\left(n_{e}+n_{D T}\right) \cdot K T}{\tau_{E}} .
$$

When the D-T plasma temperature increases in thermonuclear conditions and enough confinement is provided, the $\alpha$ particles heating increases consequently and at a certain condition it is enough to entirely compensate the power losses. At this 
point the external heating can be switched off and the plasma temperature can be sustained only by internal heating. This condition is called Ignition.

Considering constant density and temperature the ignition conditions is (Lawson criterion):

$$
n \tau_{E}>\frac{12}{<\sigma v>} \frac{k T}{E_{\alpha}} .
$$

A measure of the success of a device is the parameter $Q$ (amplification factor), which is the ratio between the thermonuclear power produced and the heating power supplied:

$$
Q=\frac{P_{\text {fusion }}}{P_{\text {exernal }}} \text {. }
$$

Since in D-T reactions $E=5 E \alpha \rightarrow Q=5 P \alpha /$ $P_{\text {heat. }}$ Thus $Q=1$ (break-even) when $P \alpha=20 \% P_{H}$. At ignition (fully ignited plasma) $\mathrm{Q}=\infty$, and $n_{\mathrm{e}} T_{\tau \mathrm{E}}$ $=$ const.

For an economical nuclear fusion reactor, the required value of $Q$ is greater than 30 .

\section{MAGNETIC CONFINEMENT DEVICES}

At the present day, the most advanced fusion reactors are toroidal shaped magnetic confinement devices.

In such devices, the plasma is confined through magnetic fields, with a confinement time of few seconds and a low pressure. The magnetic field reduces the perpendicular motion of the confined particles and balances out the plasma pressure $(\sim 10$ atm). Also, because of the toroidicity of the device there are no end losses of particles. The main definitions for a toroidal device (Figure 6) in a simple case are:

- Major axis $Z$ - axis of revolution of a torus.

- Major radius $R$ - distance from the major axis.

- Plasma magnetic axis - line along which $B p=$ 0.

- Plasma major radius $R_{0}$ - major radius to the plasma magnetic axis.

- Minor radius $r$-distance of a magnetic surface from the magnetic axis.

- Plasma minor radius $a$ - the minor radius at the plasma surface for a toroidal plasma circular cross-section.

- Toroidal field $B t$ - magnetic field in toroidal direction.

- Poloidal field $B p$ - magnetic field in poloidal direction.
- Toroidal angle $\phi$-angle around major axis.

- Poloidal angle $\theta$ - angle around plasma magnetic axis.

- Aspect ratio $=R_{0} / \alpha$.

- Inverse aspect ratio $=\alpha / \mathrm{R}_{0}$

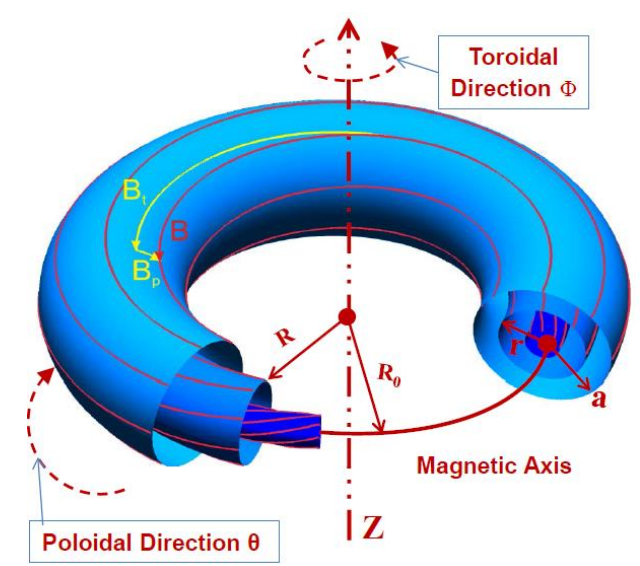

Fig. 6. Toroidal device definitions

There are two concepts of magnetic confinement, the Tokamak (axi-symmetric) (Figure 7a) [5] and the Stellarator (3D) (Figure 7b) [5].

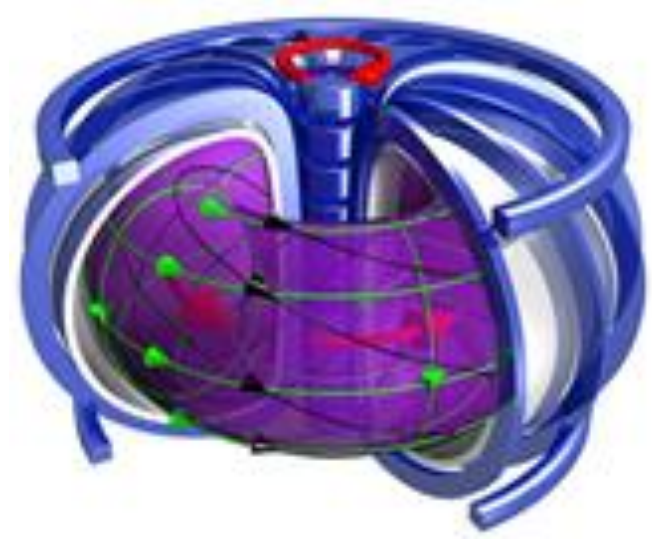

Fig. 7a. Tokamak

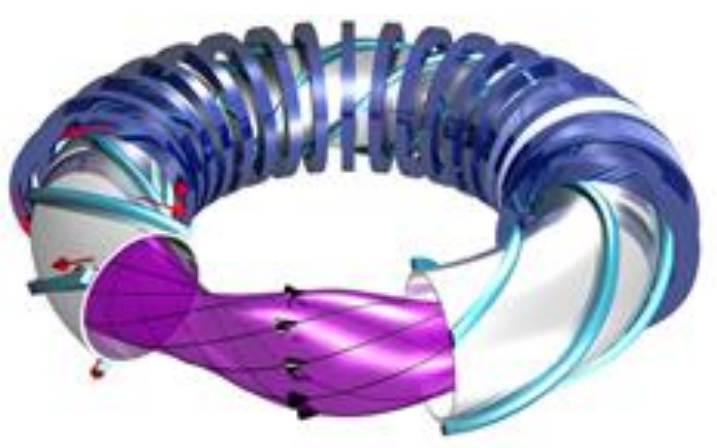

Fig. 7b. Stellarator 
The magnetic field in the Tokamak is produced by both coils and the plasma itself and in the Stellarator is produced just by the coils. The conventional Tokamaks have good thermal insulation and have exact toroidal symmetry, but the Stellarators have steady state operation and no current driven instabilities. The steady state operation in a Tokamak can be reached through a current drive and the instabilities can be managed by active control. As we can see on Figure 8, the evolution of Tokamaks is more promising.

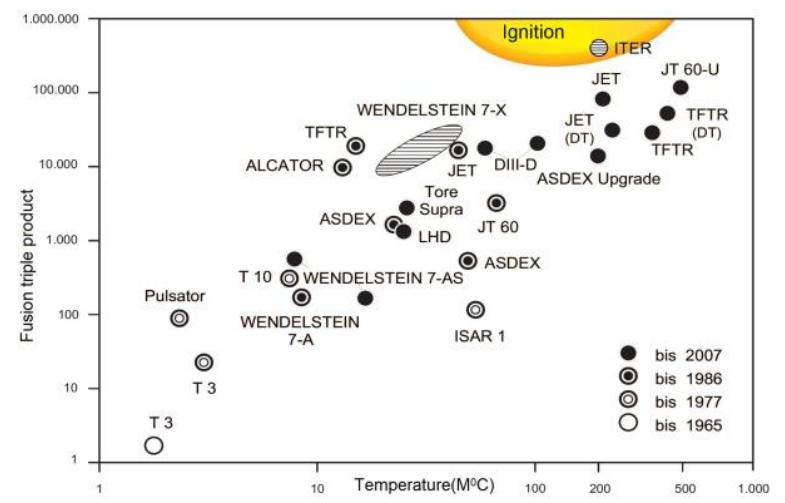

Fig. 8. Magnetic fusion on the way to energy production

\section{Tokamak concept}

The toroidal magnetic field of a Tokamak (Figure $7 \mathrm{a}$ ) is produced by the toroidal magnetic field coils and the poloidal field is produced by the plasma current, which is generated by the inner poloidal magnetic field coils. The superposition of the toroidal and poloidal fields creates a helical magnetic field which is necessary for avoiding the drifts of the plasma particles and preventing their escape to the vessel's walls. The outer poloidal magnetic field coils are used for plasma positioning and shaping.

\section{Evolution of Tokamak}

The main evolutions of the Tokamak designs since its invention (Figure 8) have been:

- Size matters - the confinement and the machine performances are depending on its size and its plasma current capabilities. High performance Tokamaks are large.

- Plasma has evolved from circular to (vertically) elongated form. Higher currents are possible without increasing the major radius, the magnet design is improved.

- The iron transformer core can be eliminated (ITER will not have it).
- The $\mathrm{Cu}$ magnetic coils are been substituted by superconducting coils.

- The diverter has replaced pumped limiter.

- The Tokamaks have improved from short pulses operation to long pulses where most components require active cooling.

- The heating systems have highly increased performances in particular for the electromagnetic wave heating. Neutral beam injectors using accelerated negative ions are substituting those using accelerated positive ions.

- Additional control coils have been added to improve operation or solve new found problems.

\section{Fusion in Tokamaks}

The D-T fusion has already been demonstrated at JET (Joint European Torus), Culham, UK in 1997 (Figure 9) and a scientific 'breakeven' has been nearly reached (with fusion power $=1.6$ times of heating power).

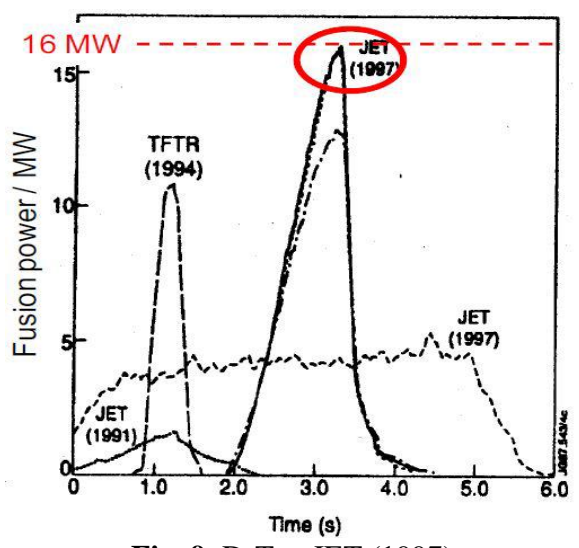

Fig. 9. D-T at JET (1997)

The parameters of the JET Tokamak are:

$$
\begin{aligned}
& R \cong 2.9 \mathrm{~m} \\
& a \cong 1 \mathrm{~m} \\
& b \cong 1.7 \mathrm{~m} \\
& B \phi \leq 3.45 \mathrm{~T}(4.0) \\
& I p \leq 4.8 \mathrm{MA}(6 \mathrm{MA}) \\
& P_{\text {aux }} \leq 37 \mathrm{MW} \\
& Q \cong 1
\end{aligned}
$$

The next, biggest fusion project is called ITER (International Thermonuclear Fusion Reactor or 'WAY' in Latin) and is located in Cadarache, France. Extrapolation towards ITER is shown on the following Figure 10. 


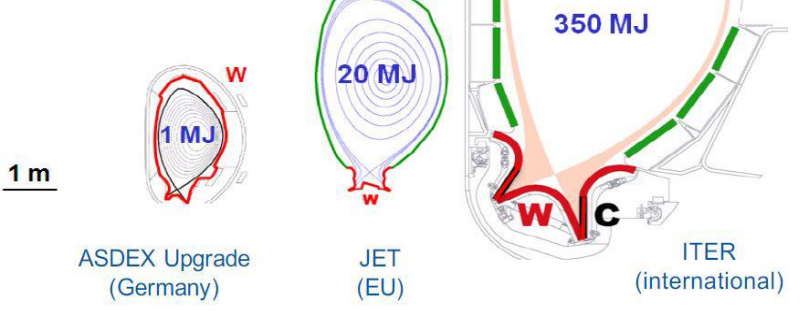

Fig. 10. Extrapolation towards ITER

The parameters of the ITER Tokamak are:

$$
\begin{aligned}
& R=6.2 \mathrm{~m} \\
& a=2 \mathrm{~m} \\
& B=5.3 \mathrm{~T} \\
& I p=15 \mathrm{MA} \\
& P_{\text {fusion }} \approx 400 \mathrm{MW}(800 \mathrm{MA}) \\
& t_{\text {discharge }} \approx 400 \mathrm{~s}(3000 \mathrm{~s}) \\
& P_{\text {heating }} \approx 37 \mathrm{MW} \\
& Q \geq 10
\end{aligned}
$$

ITER's programmatic objectives are to:

- demonstrate the scientific and technological feasibility of fusion energy for peaceful purposes,

- demonstrate extended burn of DT plasmas, with steady state as the ultimate goal,

- integrate and test all essential fusion power reactor technologies and components,

- demonstrate safety and environmental aceptability of fusion.

Figure 11 according the study results in [9], provides a summary of current efforts, showing key concepts and expected milestones, on the pathway to commercial nuclear fusion energy.

The result of this review study highlights the current plans for the development of fusion to deliver on the promise of fusion energy. Current plans to realize fusion power are continuously updated, however should be treated with caution, as they are subject to uncertainties, unknown obstacles to technological progression and resource limitations in funding and manpower; all of which may limit the ability to achieve future goals in a timely manner.

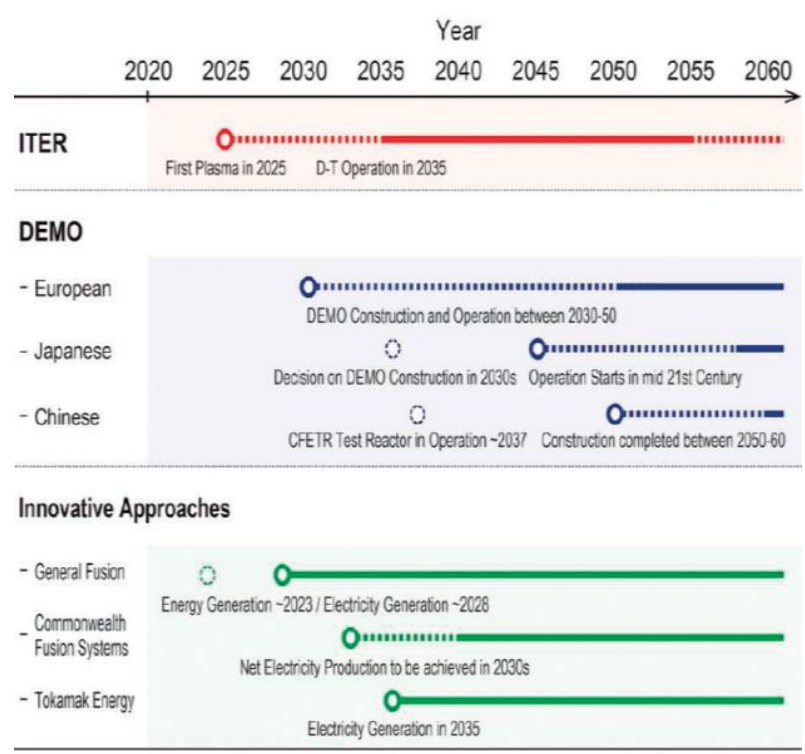

Fig. 11. Roadmap of development of nuclear fusion reactor [9]

Although fusion power plants will release small quantities of tritium to within already defined limits, they will not produce GHGs or other air pollutants. As a result, the environmental impacts associated with nuclear fusion power plants will instead be primarily attributed to construction, operation and maintenance, including fuel supply chains, and waste disposal. Environmental Life Cycle Assessments (LCA) suggest that life cycle greenhouse gas emissions of nuclear fusion electricity generation will be somewhere between 6 and $12 \mathrm{gCO}_{2} / \mathrm{kWh}$ of electricity production. This is in line with recent renewables estimates and current light water nuclear power plants. So, it is much lower than for coal power plants $\left(800 \mathrm{gCO}_{2} / \mathrm{kWh}\right)$, or $\mathrm{CC}$ gas power plant $\left(400 \mathrm{gCO}_{2} / \mathrm{kWh}\right)$.

\section{CONCLUSION}

With the constant growth of population and development of countries the total energy demand is constantly increasing. A solution to the global pollution and emission of $\mathrm{CO}_{2}$ is being looked for in renewable energy sources but the production cannot account for the demands. In comparison to fission, fusion has no radioactive waste as the end product of the reaction is helium (He). The fusion power plant is a safe and reliable source of energy which excludes potential accidents and meltdowns as in the case of fission power plants. The most effective fusion reaction on Earth is the deuterium-tritium (D$\mathrm{T}$ ) reaction. The total energy coming from the mass defect $(17.6 \mathrm{MeV})$, released as kinetic energy of the 
fusion products, is distributed according to their mass ratio $(\mathrm{He}-3.5 \mathrm{M} \mathrm{eV}, n-14.1 \mathrm{M} \mathrm{eV})$.

The neutrons, as they do not interact with the magnetic field, leave to the vessel wall of the confinement device. The $\alpha$ particles transfer their energy to the plasma through collisions and thus keep the plasma in a burning state. Magnetic confinement devices have been proven to be the best for sustaining the plasma and thus the ongoing fusion reactions. To this day, the most advanced magnetic confinement device is the Tokamak. It is a toroidal device which uses powerful magnetic fields to confine the burning plasma. The latest international Tokamak, called ITER, is set to demonstrate the feasibility of fusion energy as an effective energy source (the first burning plasma expected in 2028). In order to have a rapid market penetration, fusion will have to demonstrate the potential for competitive cost of electricity. Although this is not a primary goal for DEMO, the perspective of economic electricity production from fusion has to be set as a target, e.g. minimizing the DEMO capital costs. Building on the experience of ITER, design solutions demonstrating a reliable plant with a high availability, serving as a credible data basis for commercial energy production, will have to be pursued. Socio-economic research activities on fusion energy will also help in maintaining a long-term perspective and optimizing the strategies for market penetration of fusion. At the current time, however, it is expected that fusion energy will become a reality in less than 30 years.

\section{REFERENCES}

[1] Arbeitsgemeinschaft Energiebilanzen, Stand July 2015.

[2] EU Commission / Edgar, 2014.

[3] Courtesy of Max Planck Institut für Plasmaphysik.

[4] Chen, F. F.: Introduction to Plasma Physics and Controlled Fusion, Plenum Press, New York, 1984.

[5] Bellan, P. M.: Fundamentals of Plasma Physics, Cambridge, 2006.

[6] Жданов, С. К., Курнаев, В. А., Романовский, М. К., Цветков, И. В.: Основы физических прочессов в плазме и плазменных установках, Москва.

[7] Donné, A. J. H., Federici, G., Litaudon, X., McDonald, D. C.: Scientific and technical challenges on the road towards fusion electricity. Journal of Instrumentation, 12 (10), C10008 (2017).

[8] Federici, G., Kemp, R., Ward. D., Bachmann, C., Franke, T., Gonzalez, S., et al. Overview of EU DEMO design and R\&D activities. Fusion Engineering and Design. 89 (7), pp. 882-889 (2014), DOI: 10.1016.

[9] Shutaro Takeda and Richard Pearson; Nuclear Fusion Power Plants (in PDF). Available from: https://www.researchgate.net/publication/328902147 [accessed Apr 12, 2020].

[10] A roadmap to the realization of fusion energy, Fusion Electricity - EFDA, November 2012. 